\title{
Cereal Aphid Species (Homoptera : Aphididae) Infesting Wheat Plants and their Aphidophagous Insects at El-Khattara District, Sharkia Governorate, Egypt \\ Youssif , M. A. I. ${ }^{1}$; SH. A. M. Ali ${ }^{2}$ and Walaa M. M. Helaly ${ }^{1}$ \\ ${ }^{1}$ Plant Prot. Dept., Fac. of Agric. , Zaazig Univ., Zagazig, Egypt \\ ${ }^{2}$ Plant Protection Research Institute, Dokki, Egypt \\ * Corresponding author: Mohammed Ahmed Ibrahim Youssif \\ Tel.: +201006980317 E-mail address: m.youssif1@yahoo.com
}

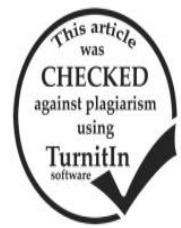

\section{ABSTRACT}

Studies on cereal aphids infesting wheat plants and their aphidophagous insects were carried out in newly reclaimed sandy area at El-Khattara district, Sharkia Governorate, Egypt during 2015-2016 and 2016-2017 growing seasons. The obtained results are summarized as follows:Four aphid species, i.e., Shizaphis graminum (Rondani), Rhopalosiphum maidis (Fitch), Rhopalosiphum padi (Linnaeus) and Macrosiphum avenae (Fabricius) were found infested wheat plants.Cereal aphids infested wheat plants from the first week of January till the last week of April. The highest populations of aphids were recorded in the first week of March and in the second week of April with counts of 711 and 1503 individuals/ sample in the first and second seasons, respectively.Six predaceous insect species belonging to four orders and five families were surveyed associated with aphid species infesting wheat plants. Coleopterous species were the most dominant, followed by the neuropterous ones, with general relative densities of 41.70 and 21.10 $\%$ of the total recorded predators, successively. Among all recorded predaceous species, Chrysoperla carnea (Stephens), Coccinella undecimpunctat $\mathrm{L}$., and Coccinella septempunctata L., were the most dominant species, comprised $21.10,15.68$ and $15.26 \%$ of the total count of the predators, respectively. The total recorded predators showed that means of 1:61.62 and 1:118.73 predators: prey ratios in the first and second seasons, respectively.Five species of hymenopterous parasitoids were emerged from mummified individuals of cereal aphids, namely, Diaeretiella rapae (M'Intosh), Aphidius colemani Viereck, Aphidius matricariae Haliday, Ephedrus sp. and Praon sp. The most dominant parasitoids were D. rapae and A. colemani with general relative densities of 35.32 and $27.12 \%$ respectively. The fluctuations of the total percentages of parasitism indicated three peaks in the first season and two ones in the second season. The mean percentage of parasitism during the first season was relatively high (6.41\%) in comparison with that in the second one $(3.60 \%)$. The correlation between cereal aphids populations and percentages of parasitism in both seasons were positive high significant

Keywords: Cereal aphids, Predators, Parasitoids, Wheat, Seasonal abundance.

\section{INTRODUCTION}

Wheat, Triticum aestivum L. (Family: Gramineae)is one of the most important cereal crops in Egypt. It is using for human food, as well as in animal and poultry feeding. The Egyptian Agricultural Policy aims to increase wheat production to reduce the gap between the consumption and production. The grown wheat area in Sharkia Governorate is about 381492 Feddan with an average production of about 2.700 tons / feddan (Anonymous, 2017 ). Quite a lot of aspects are to blame for the low yield of wheat crop production worldwide. Wheat, in all over the world has the largest cultivated area and the quantity produced is more than what of any other crop leading wheat producing countries are China, Russia, USA, France and Canada (Shah, 1994).

Most of arthropod pests belong to seven major orders: Orthoptera, Homoptera, Hemiptera, Coleoptera, Diptera, Lepidoptera and Hymenoptera. Among these cereal aphids are gaining importance since their population has increased over the last few years (Atwal, 1976; Ghanem and El-Adl (1983); Hatchett et al., 1987; ElSerafy, 1999; El-Heneidy et al., 2004; Youssef, 2006 and Ahmad et al., 2016).

Aphids are serious inset pests attacking wheat plants in Egypt, mentioned by Tantawi, (1985), who recorded losses in crop averaged $7.5-18.7 \%$ of the total wheat production in Middle and Upper Egypt. Chemical insecticides induced major well know problems such as health hazards to human and animals, destruction of biological control agents and increased resistance of insects to insecticides, (Picard, 1987). Recently, entomologists suggested Integrated Pest Management (IMP), using all other control methods which emphasize an biological control (Sehüler et al., 1999).
Since, the aphidophagous insects have important role in suppression aphid populations, the present work was conducted in the newly reclaimed pesticides - free area at El-Khattara district, Sharkia Governorate, to contribute concerning the following points:

1. Surveying the cereal aphids species and their associated aphidophagous insects on wheat punts.

2. Seasonal abundance of cereal aphids and their associated aphidophagous insects on wheat plants.

3. Effect of prevailing temperatures and relative humidities on the aphids and their aphidophagous insect.

\section{MATERIALS AND METHODS}

Field experiments were conducted in the newly reclaimed sandy areas, at El-Khattara district, Sharkia Governorate, Egypt during two successive wheat growing seasons of 2015-2016 and 2016-2017.

An area of one feddan was sowed with wheat, Triticum nestivum L., variety Miser 1 in the first week of November in each 2015 and 2016 years. Normal agricultural practices were used in the due time and no chemical control was applied.

To study the population fluctuations of aphids and aphidophagous insects, ten tillers of wheat infested with aphids were weekly selected, then picked up, placed in paper bags and transferred into laboratory, where carefully examined by the aid of stereoscopic microscope. Nymphs and adults of aphid were directly counted. Predators in most cases were directly counted, and in some few cases laboratory rearing was necessary for the immature stages till the emergence of the adults. The predacious larvae which observed on the collected samples, were separated and reared individually in Petri- dishes (10 cm diameter), provided with aphid individuals until pupation and 
emergence of the adults. Mummified individuals of the aphid were transferred gently from the infested samples using a fine brush, to test tubes $(15 \times 1 \mathrm{~cm})$, covered with pieces of cotton wool and were kept till emergence of the parasitoids. Adults and nymphs of the aphids were reared in glass jars on pieces of plant leaves until mummification of the parasitized individuals. Emerged parasitoids were collected, counted and identified.

The parasitoids and predators were identified in Biological control Dept., Plant Prot. Res. Inst., Giza, Egypt with the help of Prof. Dr. Ahmed H. El - Heneidy, Chief of Biological Control Researchers. Prevailing temperatures and relative humidities were obtained from the Meteorological Station in Zagazig Region.

Simple correlation and simple regression values were calculated according to COSTAT Computer Program (2005).

\section{RESULTS AND DISCUSSION}

1. Survey and seasonal abundance of aphid species infesting wheat plants:

1. Survey of aphid species

Four aphid species belonging to Homoptera, Aphididae were recorded infesting wheat plants, i.e., Ropalosiphum padi (Linnaeus), Schizaphis graminum (Rondani), Ropalosiphum maidis (Fitch) and Macrosiphum (=Sitobion) avenae (Fabricius).

The obtained results are in agreement with those of Tawfik and El-Husseini (2002), El-Bouhssini et al., (2003), El-Heneidy et al., (2004), Yossef (2006) and Ahmad et al., (2016). They mentioned that wheat is attacked by a few numbers of pests. The most injurious were aphids, S. graminum, S. avenae , R. maidis , R. padi and Diuraphis noxia Mord. Also, Vandereycken et al., (2015) recorded six species of aphid infested wheat plants namely : S. avenae, Sitobion fragariae Wolker, R. Padi, R. maidis, Roplasiphum insertum Walker and $\mathrm{S}$. graminum.

\section{a. Seasonal abundance of aphids}

The differentiation of aphids infesting wheat plants were not taken into consideration during the course of this investigation. So, aphids will be referred to the counting of different aphid species.

Data represented in Table (1) illustrated the fluctuations in the population of aphid complex on wheat plants under the prevailing climatic conditions through the two successive seasons of 2015-2016 and 2016-2017.

In the first season, the data arranged in Table (1 ) indicated that the aphid infestation occurred during the period from the 1st week of January till the 4th week of April 2017. During this period, the aphid population was fluctuated to showed three peaks. The first one, 524 aphids / sample was in the 2nd week of February at means of 14.9 ${ }^{\circ} \mathrm{C}$ and $57.2 \% \mathrm{RH}$. The second and highest peak, 711 aphid / sample was in the 1st week of March at means of $22.4{ }^{\circ} \mathrm{C}$ and $49.57 \%$ RH. The third and lowest one, 274 individuals/ sample, took place in the 1st week of April at means of $22.7^{\circ} \mathrm{C}$ and $53.71 \%$ RH. The maximal and minimal monthly total counts were found during March and January with 2132 and 401 individuals, respectively. The mean numbers of the aphids during the season was 256.21 individuals / sample.
Table 1. Seasonal abundance of aphid species infesting wheat plants cultivated in newly reclaimed sandy area at El- Khattara district, Sharkia Governorate during the two successive growing seasons of 20152016 and 2016-2017.

\begin{tabular}{|c|c|c|c|c|c|c|}
\hline \multirow{3}{*}{$\begin{array}{l}\text { Weekly } \\
\text { date of } \\
\text { sample }\end{array}$} & \multirow{2}{*}{\multicolumn{2}{|c|}{$\begin{array}{c}\begin{array}{c}\text { Number of } \\
\text { aphids/sample }\end{array} \\
(10 \text { tillers })\end{array}$}} & \multicolumn{4}{|c|}{ Corresponding means of } \\
\hline & & & \multicolumn{2}{|c|}{ Temp. ${ }^{\circ} \mathrm{C}$} & \multicolumn{2}{|c|}{ RH \% } \\
\hline & $\begin{array}{c}2015- \\
2016\end{array}$ & $\begin{array}{c}2016- \\
2017\end{array}$ & $\begin{array}{c}2015- \\
2016\end{array}$ & $\begin{array}{l}\text { 2016- } \\
2017\end{array}$ & $\begin{array}{c}2015- \\
2016\end{array}$ & $\begin{array}{l}\text { 2016- } \\
2017\end{array}$ \\
\hline$\overline{\text { Dec. } .4^{t h}}$ & 0 & 20 & 21.0 & 18.0 & 66.6 & 59.5 \\
\hline Total & 0 & 20 & & & & \\
\hline Jan., $1^{s t}$ & 25 & 60 & 18.7 & 18.3 & 64.3 & 61.5 \\
\hline $2^{\text {nd }}$ & 66 & 133 & 18.3 & 17.2 & 66.9 & 60.2 \\
\hline $3^{r d}$ & 90 & 242 & 14.6 & 17.7 & 64.4 & 60.0 \\
\hline $4^{\text {th }}$ & 220 & 461 & 13.7 & 16.7 & 62.3 & 63.2 \\
\hline $5^{\text {th }}$ & - & 706 & 14.0 & 16.3 & 60.5 & 60.1 \\
\hline Total & 401 & 1602 & & & & \\
\hline Feb., $1^{s t}$ & 352 & 878 & 15.1 & 18.5 & 68.1 & 59.3 \\
\hline $2^{\text {nd }}$ & 524 & 472 & 15.4 & 15.3 & 60.5 & 63.2 \\
\hline $3^{r d}$ & 419 & 633 & 16.1 & 16.3 & 60.9 & 63.7 \\
\hline $4^{\text {th }}$ & 504 & 782 & 15.4 & 18.5 & 60.8 & 59.3 \\
\hline Total & 1799 & 2765 & & & & \\
\hline Mar.,1 & 711 & 1021 & 15.5 & 21.3 & 63.0 & 58.2 \\
\hline $2^{n d}$ & 509 & 845 & 14.8 & 19.9 & 69.5 & 63.3 \\
\hline $3^{r d}$ & 389 & 782 & 14.6 & 19.2 & 70.0 & 62.1 \\
\hline $4^{\text {th }}$ & 275 & 918 & 14.3 & 18.3 & 63.0 & 60.3 \\
\hline $5^{\text {th }}$ & 248 & . & 18.9 & 19.3 & 63.1 & 62.0 \\
\hline Total & 2132 & 3566 & & & & \\
\hline Apri., $1^{s t}$ & 274 & 1027 & 20.6 & 20.3 & 63.4 & 59.2 \\
\hline $2^{\text {ndd }}$ & 194 & 1503 & 15.7 & 20.0 & 66.1 & 53.9 \\
\hline $3^{r d}$ & 63 & 1050 & 15.8 & 25.9 & 64.3 & 50.3 \\
\hline $4^{\text {th }}$ & 5 & 490 & 26.0 & 22.3 & 64.8 & 53.9 \\
\hline Total & 536 & 4070 & & & & \\
\hline May, $1^{s t}$ & - & 285 & 25.9 & 23.5 & 59.3 & 55.2 \\
\hline $2^{\text {nd }}$ & - & 40 & 26.5 & 24.9 & 52.3 & 50.3 \\
\hline Total & & 325 & & & & \\
\hline General & 4868 & 12348 & & & & \\
\hline Mean & 256.21 & 588.00 & & & & \\
\hline
\end{tabular}

Data of the second season in Table (1) indicated similar trend, whereas three peaks were recorded. The first one was the highest, with a number of 1503 aphids/ 10 tillers, occurred during 2 nd week of April at means of $20.0^{\circ} \mathrm{C}$ and $53.9 \% \mathrm{RH}$. The second peaks was recorded in the1st week of March with number of 1021 aphids/ 10 tillers at means of $21.3^{\circ} \mathrm{C}$ and $58.2 \% \mathrm{RH}$. The third and intermediate one, 878 aphids / sample, was recorded in the 1st week of February at means of 18.5 and 59.3. The highest and lowest monthly total number of the aphids were found during December and April, with counts of 20 and 4070 individuals, respectively. The mean numbers of the aphids during the seasons was 588.0 individuals / samples. The aphids population in the second season was relatively higher as compared with that in the first one, with counts of 12348 and 4868 individuals, respectively. The obtained results are in agreement with those of the following investigators. Ali and Darwish (1990) in Assiut, Egypt who indicated that the population density of aphids reached $10 \%$ of the maximum population density in mid March. Ali et al., (1991) in Egypt revealed that the numbers of $\mathrm{S}$. graminum and $\mathrm{R}$. padi peaked in late February and in the first half of March during two respective seasons. El-Heneidy et al. (2004), reported that 
the population densities of cereal aphids on wheat plants in Sakha and Sides region occurred in high numbers during February and March.

Rana (2005) indicated that S. avenae population was the highest during the second week of March and started declining gradually and disappeared in the second week of April. Also, Abd El-Megid et al. (2007) in Egypt, indicated that the infestation by aphids on wheat started during the 2nd week of February. The population reached a peak during the 1 st week of March and disappeared towards the end of April. Vandereycken et al. (2015) reported that the population densities of aphids infesting wheat plants occurred during March. Ahmed et al. (2016) in Pakistan revealed that the mean number of infestation of aphid population in wheat (7.87) was recorded on the crop sown on 15th October which gradually decreased up to 2.32 in crop sown on 1st January. The aphid infestation on wheat started from 4th week of January to 3rd week of March increased from 0.67 to 14.40 which decreased up to 1.82 respectively during 2 nd week of April.

There were negative high significant and positive insignificant correlations between mean of temperatures and numbers of the aphid during the two respective seasons (Table 2). Also, relative humidities had insignificant effects, being negative insignificant in the first and second seasons, respectively.

2. Survey and Seasonal abundance of the natural enemies associated with wheat aphids.

1. Survey and relative densities of the predaceous insects:

Data presented in Table (3), showed that seven predaceous species belonging to six families and five orders were recorded. The orders could be arranged asendingly according to their general relative densities during the two successive seasons of study as follows : Acarina (9.43\%), Hemiptera (13.34\%), Diptera $(14.43 \%)$, Neuroptera $(21.10 \%)$ and Coleoptera $(41.70 \%)$. Acarina species included unidentified several species. Hemiptera was represented only by Orius laevigatus Fabricus. ( Anthocoridae). Diptera was found only by Metasyrphus corollae (Fabricius). Neuroptera was recorded by one species, Chrysoperla carnea (Stephens). Coleopterous ones were Coccinella septempunctata Linnaeus, Coccinella undecimpunctata Linnaeus (Coccinellidae) and Paederus alfierii (Koch) (Staphylinidae) .

Table 2. Simple correlation coefficient (r) and simple regression coefficient (b) between weekly mean numbers of aphids infesting wheat plants and corresponding means of temperature $\left({ }^{\circ} \mathrm{C}\right)$ and relative humidity $(\mathrm{RH} \%)$ in newly reclaimed sandy area at El- Khattara district, Sharkia Governorate during the two successive growing seasons, 2015-2016 and 2016-2017.

\begin{tabular}{lcccc}
\hline Considered & \multicolumn{2}{c}{ r (Values) } & \multicolumn{2}{c}{ b (Values) } \\
\cline { 2 - 5 } $\begin{array}{l}\text { weather } \\
\text { factor }\end{array}$ & $\begin{array}{c}\text { First } \\
\text { season }\end{array}$ & $\begin{array}{c}\text { Second } \\
\text { season }\end{array}$ & $\begin{array}{c}\text { First } \\
\text { season }\end{array}$ & $\begin{array}{c}\text { Second } \\
\text { season }\end{array}$ \\
\hline $\begin{array}{l}\text { Numbers of aphid } \\
\text { and mean temp. }{ }^{\circ} \mathrm{C}\end{array}$ & $-0.578^{* *}$ & $0.157^{\text {n.s }}$ & -7.930 & 2.003 \\
$\begin{array}{l}\text { Numbers of aphid } \\
\text { and mean RH \% }\end{array}$ & $-0.192^{\text {n.s }}$ & $-0.120^{\text {n.s }}$ & -2.248 & -2.147 \\
\hline
\end{tabular}

n.s = Non significant $\quad * *=$ Highly significant

Table 3. Survey and relative densities of aphidophagous insect predators associated with aphids infesting wheat plants cultivated in newly reclaimed sandy area at El- Khattara district, Sharkia Governorate during 2015 - 2016 and $2016-2017$ growing seasons.

\begin{tabular}{|c|c|c|c|c|c|c|c|c|}
\hline \multirow{2}{*}{ Order } & \multirow{2}{*}{ Family } & \multirow{2}{*}{ Species } & \multicolumn{4}{|c|}{$2015-20162016-2017$} & \multicolumn{2}{|c|}{ General } \\
\hline & & & No. & $\%$ & No. & $\%$ & No. & $\%$ \\
\hline Acarina & Unidentified & (True spiders) Unidentified species & 73 & 10.93 & 40 & 7.53 & 113 & 9.43 \\
\hline Total & & & 73 & & 40 & & 113 & \\
\hline & & & & 10.93 & & 7.53 & & 9.43 \\
\hline Hemiptera & Anthocoridae & Orius laevigatus Fabricius & 94 & 14.07 & 66 & 12.43 & 160 & 13.34 \\
\hline Total & & & 94 & & 66 & & 160 & \\
\hline$\%$ & & & & 14.07 & & 12.43 & & 13.34 \\
\hline Diptera & Syrphidae & Metasyrphus (=Syrphus) corollae (Fabricius) & 111 & 16.62 & 62 & 11.68 & 173 & 14.43 \\
\hline $\begin{array}{l}\text { Total } \\
\%\end{array}$ & & & 111 & $6 ?$ & 62 & 168 & 173 & 14 \\
\hline Neuroptera & Chrysopidae & Chrysoperla carnea (Stephens) & 171 & 25.60 & 82 & 15.44 & 253 & 21.10 \\
\hline $\begin{array}{l}\text { Total } \\
\%\end{array}$ & & & 171 & 25.60 & 82 & 15.44 & 253 & 21.10 \\
\hline Coleoptera & a. Coccinellidae & Coccinella septem & 79 & 36.07 & 104 & 37.01 & 183 & 36.60 \\
\hline & & Coccinella undecimpunctata Linnaeus & 77 & 35.16 & 111 & 39.50 & 188 & 37.60 \\
\hline & b. Staphylinidae & Paederus alfierii (Koch) & 63 & 28.77 & 66 & 23.49 & 129 & 25.80 \\
\hline $\begin{array}{l}\text { Total } \\
\%\end{array}$ & & & 219 & 32.78 & 281 & 52.92 & 500 & 41.70 \\
\hline Gener & & & 668 & & 531 & & 1199 & \\
\hline & & & & 100.00 & & 100.00 & & 100.00 \\
\hline
\end{tabular}

Abd El-Megid et al., (2007) recorded five insect predators belonging to three orders and four families associated with wheat aphids. They were C. undecimpunctata , C. septempunctata, P. alfierii, C. carnea and M. corollae. Also, the present results coincided with those of Ghanim and El-Adl (1983), El-Heneidy and Attia (1988), Alhag et al., (1996), Abou -Elhagag and AbdelHafez (1998) who stated that the most imported predators attacking wheat aphids were coccinellids, chrysopid and staphylinids. Also, Vandereycken et al., (2015) surveyed seven aphidophagous ladybirds viz., C. undecimpunctata, C. septempunctata, Coccinella quinquepunctata Linnaeus, Harmonia axyridis Pallas, Hippodamia undecimnotata Schneider, Hippodamia variegate Goeze and Propylea quatuordecimpunctata Linnaeus on aphids, infesting wheat plants. 
According to Ahmad et al. (2016) C. carnea Syrphus sp., Coccinella sp. and Episyrphus balteatus De Geer) were recorded associating with aphids on wheat plants.

Junhe et al., (2017) in China, recorded six predaceous species associated with cereal aphids infested wheat plants namely : C. septempunctata, Syrphus nitens (Zetterstedt) , Syrphus cylindrical, Chrysopa sinica (Tjeder), Chlaenivs pallipes Gebler and Pardosa astrigera.

2. Seasonal abundance of aphidophagous insect predators:

The seasonal abundance of aphidophagous insect predators are presented in Tables 4 and 5 .

\section{Chrysoperla carnea (Stephens)}

During the first season (Table 4), the first occurrence of this predator was detected in the $4^{\text {th }}$ week of January associated with 220 aphids individuals at means of $11.7^{\circ} \mathrm{C}$ and $66.7 \% \mathrm{RH}$.

It must be noted that, the aphid started to appear three weeks before. Afterwards, the number of the green lacewing was fluctuated between eight and twelve individuals reaching its peak of occurrence, 24 individuals, in the $2^{\text {nd }}$ week of April associated with 194 aphids at means of $26.4{ }^{\circ} \mathrm{C}$ and $40.7 \%$ RH.

Table 4. Seasonal abundance of aphidophagous insect predators in relation to cereal aphids, temperature and relative humidity on wheat plants cultivated in newly reclaimed sandy area at El- Khattara district, Sharkia Governorate during the first growing season of 2015-2016 .

\begin{tabular}{|c|c|c|c|c|c|c|c|c|c|c|c|c|}
\hline \multirow[b]{3}{*}{ 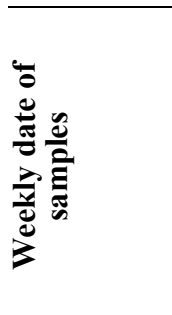 } & \multirow[b]{3}{*}{ 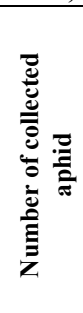 } & \multicolumn{9}{|c|}{ Number of collected predators } & \multirow{2}{*}{\multicolumn{2}{|c|}{$\begin{array}{c}\text { Corresponding } \\
\text { means of } \\
\end{array}$}} \\
\hline & & \multicolumn{3}{|c|}{ Coleopterous } & \multirow{2}{*}{ Neuropterous } & \multirow[b]{2}{*}{ 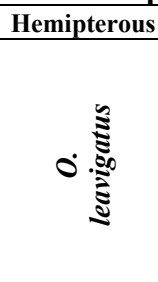 } & \multirow[b]{2}{*}{ 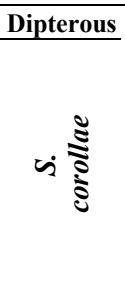 } & \multirow[b]{2}{*}{ 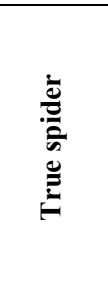 } & \multirow[b]{2}{*}{ 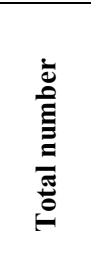 } & \multirow[b]{2}{*}{ 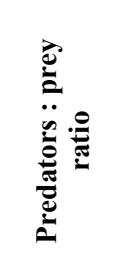 } & & \\
\hline & & ن & 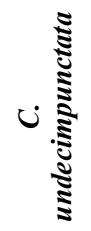 & $2: \frac{: 5}{8}$ & & & & & & & ט & $\ddot{\bar{x}} 0^{\circ}$ \\
\hline Jan.,2016 $1^{\text {st }}$ & 25 & 0 & 0 & 0 & 0 & 0 & 0 & 0 & 0 & $0: 25.0$ & 14.4 & 50.0 \\
\hline $2^{\text {nd }}$ & 66 & 2 & 0 & 0 & 0 & 0 & 0 & 0 & 2 & $1: 33.0$ & 15.7 & 60.0 \\
\hline $3^{r d}$ & 90 & 3 & 0 & 2 & 0 & 0 & 0 & 0 & $\overline{5}$ & $1: 18.0$ & 14.3 & 53.4 \\
\hline $4^{\text {th }}$ & 220 & 4 & 3 & 3 & 1 & 0 & 0 & 0 & 11 & $1: 20.0$ & 11.7 & 66.7 \\
\hline Total & 401 & 9 & 3 & 5 & 1 & 0 & 0 & 0 & 18 & $1: 22.28$ & & \\
\hline Feb., $\quad 1^{s t}$ & 352 & 8 & 8 & 5 & 6 & 0 & 3 & 0 & 30 & $1: 11.73$ & 13.0 & 67.5 \\
\hline $2^{\text {nd }}$ & 524 & 6 & 6 & 7 & 8 & 0 & 6 & 2 & 35 & $1: 14.97$ & 14.9 & 57.2 \\
\hline $3^{r a}$ & 419 & 5 & 5 & 5 & 5 & 3 & 7 & 4 & 34 & $1: 12.32$ & 20.3 & 46.4 \\
\hline $4^{\text {th }}$ & 504 & 3 & 4 & 4 & 3 & 4 & 8 & 6 & 32 & $1: 15.75$ & 19.5 & 51.0 \\
\hline Total & 1799 & 22 & 23 & 41 & 22 & 7 & 24 & 12 & 131 & $1: 13.73$ & & \\
\hline March, $1^{s t}$ & 711 & 12 & 10 & 8 & 12 & 6 & 12 & 10 & 70 & $1: 10.16$ & 22.4 & 49.5 \\
\hline $2^{n d}$ & 509 & 8 & 8 & 6 & 10 & 5 & 7 & 7 & 51 & 1:9.98 & 20.5 & 48.7 \\
\hline $3^{r d}$ & 389 & 6 & 6 & 3 & 13 & 6 & 8 & 5 & 47 & $1: 8.28$ & 21.8 & 43.0 \\
\hline $4^{\text {th }}$ & 275 & 3 & 5 & 2 & 15 & 8 & 10 & 8 & 51 & $1: 5.39$ & 20.0 & 47. \\
\hline $5^{t h}$ & 248 & 2 & 3 & 2 & 16 & 10 & 12 & 9 & 54 & $1: 4.59$ & 21.6 & 43.8 \\
\hline Total & 2132 & 31 & 32 & 21 & 66 & 35 & 49 & 39 & 273 & $1: 7.81$ & & \\
\hline April, & 274 & 4 & 6 & 4 & 18 & 12 & 16 & 12 & 72 & $1: 3.81$ & 22.7 & 53.7 \\
\hline $2^{n d}$ & 194 & 10 & 8 & 7 & 24 & 15 & 10 & 7 & 81 & $1: 2.40$ & 26.4 & 40.7 \\
\hline $3^{r a}$ & 63 & 3 & 3 & 5 & 22 & 18 & 7 & 3 & 61 & $1: 1.03$ & 25.8 & 44.7 \\
\hline $4^{\text {th }}$ & 5 & 0 & 2 & 0 & 18 & 7 & 5 & 0 & 32 & $1: 0.16 .0$ & 28.2 & 36.4 \\
\hline Total & 356 & 17 & 19 & 16 & 82 & 52 & 38 & 22 & 246 & $1: 45.0$ & & \\
\hline General total & 4868 & 79 & 77 & 63 & 171 & 94 & 111 & 73 & 668 & & & \\
\hline $\begin{array}{l}\text { Predators } \\
\text { prey ratio }\end{array}$ & & $1: 61.62$ & $1: 63.22$ & $1: 77.27$ & $1: 28.47$ & $1: 51.79$ & $1: 43.86$ & $1: 66.68$ & $1: 7.29$ & & & \\
\hline
\end{tabular}

The maximum total monthly count of the predator, 82 individuals, was recorded during Mach. The lowest value, one individuals, was obtained during January. The mean of predator: prey ratio during the season was 1 : 28.47 .

In the second season (Table 5 ), the first appearance of the predator was detected in the $4^{\text {th }}$ week of January with two individuals/ 461 aphids at means of $16.7^{\circ} \mathrm{C}$ and $63.2 \%$ RH. Its population increased gradually, reaching a peak of 14 predators / 1021 aphids in the first week of March at means of $21.3^{\circ} \mathrm{C}$ and $58.2 \% \mathrm{RH}$. The maximum monthly total number, 38 green lacewing / 3566 aphids, was recorded during March, and the lowest one, six predators / 1602 aphids, occurred during January. The predators : prey ratio during the season was $1: 150.59$.
The mean number of the predator fluctuated during December and January, and increased gradually to reach its maximum during February and March, then decreased towards the end of the seasons, in April.

Many investigators mentioned that the important role of C., carnea in suppressing aphids population on wheat and maintaining them under the economic injury levels. El-Aish- Hana et al., (2004) recorded C. carnea as main predator of cereal aphid on wheat and barley plants, El-Heneidy et al., (2004) stated that the trend of the population density of the predators depends mainly on densities of aphids. Abd El-Megid et al., (2007) stated that the highest number of the C. carnea, five individuals, was recorded during the $2^{\text {nd }}$ week of March associated with 147 aphids. The number of the green lacewing decreased 
gradually till disappeared completely at the end of the seasons.

Vandereycken et al., (2015) revealed that C.carnea was recorded early in the season and played a substantial role in suppressing aphid populations and maintaining them below the economic injury level. The mean numbers of the predator per trap per week were 0.127 and 0.134 during two successive seasons of study. Ahmed et al. (2016) reported that the highest mean number population of C. carnea was seen on wheat $(0.16)$ sown on $1^{\text {st }}$ November,$C$. carnea appeared on wheat $(0.07)$ during $2^{\text {nd }}$ week of February which increased up to 0.30 , respectively during $3^{\text {rd }}$ week of March and then declined .

\section{Metasyrphus corolla) (Fabricius):}

In the first season, the data obtained in Table (4) revealed that predator was detected during the period from the $1^{\text {st }}$ week of February till the $4^{\text {th }}$ week of April. The predator population appeared two peaks during the season. The first one , 12 individuals / 711 aphids, occurred in the $1^{\text {st }}$ week of March, synchronized with the highest population of the aphid at mean of $22.4{ }^{\circ} \mathrm{C}$ and $49.5 \%$ RH. The second peak , 16 predators/ 274 aphids, was recorded in the $1^{\text {st }}$ week of April at means of $22.7^{\circ} \mathrm{C}$ and $53.7 \%$ RH. The highly total monthly count, 49 individuals, was obtained during March. The mean ratio of Predator : prey ratios during the season was 1:43.86.

Table 5. Seasonal abundance of aphidophagous insect predators in relation to cereal aphids, temperature and relative humidity on wheat plants cultivated in newly reclaimed sandy area at El- Khattara district, Sharkia Governorate during the second growing season of 2016-2017.

\begin{tabular}{|c|c|c|c|c|c|c|c|c|c|c|c|c|}
\hline \multirow{3}{*}{ 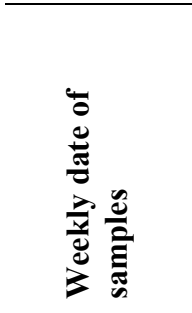 } & \multirow[b]{3}{*}{ 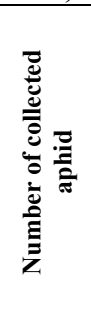 } & \multicolumn{9}{|c|}{ Number of collected predators } & \multirow{2}{*}{\multicolumn{2}{|c|}{$\begin{array}{c}\text { Corresponding } \\
\text { means of }\end{array}$}} \\
\hline & & \multicolumn{3}{|c|}{ Coleopterous } & \multirow{2}{*}{ 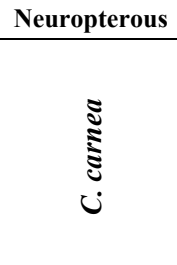 } & \multirow[b]{2}{*}{ 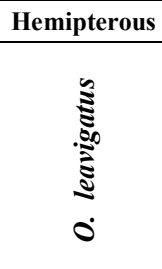 } & \multirow[b]{2}{*}{ 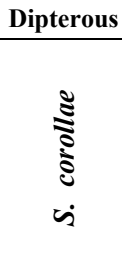 } & \multirow[b]{2}{*}{ 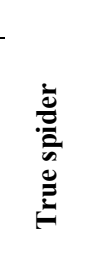 } & \multirow[b]{2}{*}{ 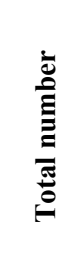 } & \multirow[b]{2}{*}{ 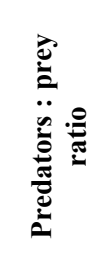 } & & \\
\hline & & ن & ن & 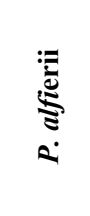 & & & & & & & $\stackrel{u}{\stackrel{0}{\Xi}}$ & $\overrightarrow{\underline{x}} \partial^{\circ}$ \\
\hline$\overline{\text { Dec. } 2016,4^{\text {th }}}$ & 20 & 0 & 0 & 0 & 0 & 0 & 0 & 0 & 0 & $0: 00.0$ & 18.0 & 59.5 \\
\hline Total & 20 & 0 & 0 & 0 & 0 & 0 & 0 & 0 & 0 & $0: 00.0$ & & \\
\hline Jan., $20171^{s t}$ & 60 & 2 & 0 & 0 & 0 & 0 & 0 & 0 & 2 & $1: 30.0$ & 18.3 & 61.5 \\
\hline $2^{\text {nd }}$ & 133 & 3 & 1 & 0 & 0 & 0 & 0 & 0 & 4 & $1: 33.25$ & 17.2 & 60.2 \\
\hline $3^{r d}$ & 242 & 3 & 3 & 0 & 0 & 0 & 0 & 0 & 6 & $1: 40.33$ & 17.7 & 60.0 \\
\hline $4^{\text {th }}$ & 461 & 4 & 5 & 2 & 2 & 0 & 2 & 0 & 15 & $1: 30.73$ & 16.7 & 63.2 \\
\hline $5^{\text {th }}$ & 706 & 5 & 7 & 3 & 4 & 0 & 2 & 0 & 21 & $1: 33.62$ & 16.3 & 60.1 \\
\hline Total & 1602 & 17 & 16 & 5 & 6 & 0 & 4 & 0 & 48 & $1: 33.38$ & & \\
\hline $\begin{array}{ll}\text { Feb., } & 1^{s t}\end{array}$ & 878 & 8 & 7 & 4 & 6 & 0 & 4 & 2 & 31 & $1: 28.32$ & 18.5 & 59.3 \\
\hline $2^{\text {nd }}$ & 472 & 12 & 10 & 5 & 11 & 3 & 3 & 3 & 47 & $1: 10.04$ & 15.3 & 63.2 \\
\hline $3^{r d}$ & 633 & 7 & 12 & 5 & 8 & 5 & 2 & 5 & 44 & 1:14.39 & 16.3 & 63.7 \\
\hline $4^{\text {th }}$ & 782 & 5 & 16 & 6 & 6 & 6 & 2 & 7 & 48 & $1: 16.29$ & 18.5 & 59.3 \\
\hline Total & 2765 & 32 & 45 & 20 & 31 & 14 & 11 & 17 & 170 & $1: 16.26$ & & \\
\hline March, $1^{s t}$ & 1021 & 15 & 18 & 17 & 14 & 12 & 6 & 8 & 90 & $1: 11.34$ & 21.3 & 58.2 \\
\hline $2^{\text {nd }}$ & 845 & 13 & 12 & 8 & 10 & 18 & 8 & 6 & 67 & $1: 12.61$ & 19.9 & 63.3 \\
\hline $3^{r d}$ & 782 & 10 & 9 & 6 & 8 & 7 & 5 & 4 & 49 & $1: 15.96$ & 19.2 & 62.1 \\
\hline $4^{\text {th }}$ & 918 & 8 & 6 & 5 & 6 & 5 & 4 & 3 & 37 & $1: 24.81$ & 18.3 & 60.3 \\
\hline Total & 3566 & 46 & 45 & 36 & 38 & 42 & 23 & 21 & 243 & 1:14.67 & & \\
\hline April, $1^{\text {st }}$ & 1027 & 6 & 5 & 3 & 4 & 10 & 10 & 2 & 40 & $1: 25.68$ & 20.3 & 59.2 \\
\hline $2^{\text {nd }}$ & 1503 & 3 & 0 & 2 & 3 & 8 & 8 & 0 & 24 & $1: 62.63$ & 20.0 & 53.9 \\
\hline $3^{r d}$ & 1050 & 0 & 0 & 0 & 0 & 0 & 6 & 0 & 6 & $1: 175.00$ & 25.9 & 50.3 \\
\hline $4^{\text {th }}$ & 490 & 0 & 0 & 0 & 0 & 0 & 0 & 0 & 0 & $0: 490.00$ & 22.3 & 53.9 \\
\hline Total & 4070 & 9 & 5 & 5 & 7 & 18 & 24 & 2 & 70 & $1: 58.14$ & & \\
\hline May, $1^{s t}$ & 285 & 0 & 0 & 0 & 0 & 0 & 0 & 0 & 0 & $0: 285.00$ & 23.5 & 55.2 \\
\hline $2^{\text {nd }}$ & 40 & 0 & 0 & 0 & 0 & 0 & 0 & 0 & 0 & $0: 40.00$ & 24.9 & 50.3 \\
\hline Total & 325 & 0 & 0 & 0 & 0 & 0 & 0 & 0 & 0 & $0: 325.00$ & & \\
\hline General total & 12348 & 104 & 111 & 66 & 82 & 66 & 62 & 40 & 531 & & & \\
\hline Predators & & 1: & 1: & $\begin{array}{c}1: \\
18709\end{array}$ & 1: & 1: & 1: & 1: & 1: & & & \\
\hline
\end{tabular}

In the second season, the data presented in Table (5) demonstrated that this predator was observed from the $4^{\text {th }}$ week of January till the $3^{\text {rd }}$ week of April. During this period, the predator population showed three peaks during the season. The first lower activity peak records four predators / 878 aphids in the $1^{\text {st }}$ week of February at means of $18.5^{\circ} \mathrm{C} 59.3 \% \mathrm{R}$. H. The second and intermediate one, eight predators / 845 aphids, was recorded in the $2^{\text {nd }}$ week of March at means of $19.9 \mathrm{C}$ and $63.3 \%$ R.H. The third peak records 10 predators/ 1027 aphids, was detected in the $1^{\text {st }}$ week of April at means of 20.3 and $59.2 \% \mathrm{RH}$. The maximum total monthly counts 24 individuals/ 4070 aphids was recorded during April while the minimum value of four predators/ 1602 aphids was obtained during 
January . The predator showed a mean ratio of one individual to 199.16 aphids during the season. Abd ElMegid et al. (2007) stated that the total monthly count of M. corollae was 15 and eight individuals during February and March, respectively. The mean of predator : prey ratio was 1: 55.22. Also, Ahmad et al., (2016) reported that the highest mean number population of $\mathrm{M}$. corollae was recorded on wheat $(0.27)$ sown on $1^{\text {st }}$ week of November. Syrphid flies appeared on wheat $(0.04)$ during $2^{\text {nd }}$ week of February and their mean number increased up to 0.70 , respectively during $3^{\text {rd }}$ week of March .

\section{Coccinella septempunctata Linnaeus:}

In the first season, the data obtained in Table (4) demonstrated that this predator was observed from the $2^{\text {nd }}$ week of January to the $3^{\text {rd }}$ week of April. The population fluctuated, showing three peaks. The first peak, eight predators/ 352 aphids, took place in the $1^{\text {st }}$ week of February at means $13.0{ }^{\circ} \mathrm{C}$ and $67.59 \% \mathrm{RH}$. The second and highest one of 12 individuals /711 aphids, was found in the $1^{\text {st }}$, weak of March at means of $22.4^{\circ} \mathrm{C}$ and $49.5 \%$ RH. The third peak, 10 predators/ 194 aphids was obtained in the $2^{\text {nd }}$ week of April at means of $26.4{ }^{\circ} \mathrm{C}$ and $40.7 \% \mathrm{RH}$. The highest total monthly number of 31 predators / 2132 aphids was recorded during March, while the lowest value of nine predators / 401 aphids, was noticed during January. The mean Predator prey ratio of $C$. septempunctata : aphids during the season was $1: 61.62$.

As shown in Table (5) in the second season of study, the ladybird beetle was detected through the period from the $1^{\text {st }}$ week of January to the $2^{\text {nd }}$ week of April, showed two peaks of activity. The first one, 12 predators/ 472 aphids, was in the $2^{\text {nd }}$ week of February at means of $15.3^{\circ} \mathrm{C}$ and $63.2 \% \mathrm{RH}$. The second and highest peak, 15 predators / 1021 aphids, took place in the $1^{\text {st }}$ week of March at means of $21.3^{\circ} \mathrm{C}$ and $58.2 \%$ $\mathrm{RH}$. The highly total monthly count of the predator, 46 individuals /3566 aphids, was found during March, while the minimum value, nine predators $/ 4070$ aphids, was obtained during April. The predator indicated a mean ratio of 1: 118.73 preys.

Khan et al.,(2003) stated that peak population of $C$. septempunctata in the middle of March, declined onward and came to a sudden end by the last week of April on wheat plants infesting with aphids. Also, Sajoqi et al. (2009) recorded the highest number of $C$. septempunctata during the $3^{\text {rd }}$ week of March. The population of ladybird beetle started decline with the decrease in aphid population and in the last week of April the lowest population of the predator was recorded.

\section{Coccinella undecimpunctata Linnaeus:}

In the first season, as shown in Table (4), the predator was detected from the $4^{\text {th }}$ week of January till the $4^{\text {th }}$ week of April. Generally the predator population was fluctuated, showing three peaks. The first one showed eight predators/ 352 aphids in the $3^{\text {rd }}$ week of February at means of $13.0{ }^{\circ} \mathrm{C}$ and $67.59 \% \mathrm{RH}$. The second peak with ten predators / 711 aphids, took place in the $1^{\text {st }}$ week of March. The third one of eight predators/ 194 aphids, was recorded in the $2^{\text {nd }}$ week of April at means of $26.4{ }^{\circ} \mathrm{C}$ and $40.71 \%$ $\mathrm{RH}$. The maximum total monthly counts, 32 individuals / 2132 aphids, was recorded during March, while the minimum value of three predators / 401 aphids was obtained during January. The predator showed a mean ratio of one individual to 63.22 aphids during the season.

In the second season (Table 5), the number of the predator was relatively higher as compared with that in the first season. The predator started to appear with one individual in the $2^{\text {nd }}$ week of January, three weeks latter after appearance of the aphid infestation. The predator population was fluctuated showing a distinct peak of 18 predators/ 1021 aphids, synchronized with that of the aphid in the $1^{\text {st }}$ week of March at means of $21.3^{\circ} \mathrm{C}$ and $58.2 \%$ RH. The maximum monthly total counts of 45 predators occurred in February and March, while the lowest value of five predators/ 4070 aphids was recorded during April. The mean of predator : prey ratio during the season was 1: 111.24

Abd El-Megid et al. (2007) stated that the maximum monthly total count of $C$. undecimpunctata was recorded during April. Meanwhile, the lowest value, one individual, was obtained during February. The mean of predator : prey ratio during the season was 1: 30.77 . Ahmed et al. (2016) mentioned that the population of $C$. undecimpunctata was started on wheat crop sown on $15^{\text {th }}$ October which gradually declined by subsequent sowing dates. The highest population of ladybird beetle was recorded on wheat crop sown on $1^{\text {st }}$ November ranging from 0.15 which declined up to 0.07 in crop sown on $1^{\text {st }}$ January.

5. Total number of aphidophagous predators in relation with aphid infestation :

Data of the first season (Table 4 ), indicated that the initial aphids infestation was recorded in the second week of January 2015, while the first record of the aphidophagous predators, two individuals, was in the $2^{\text {nd }}$ week of January, one week later, at means of $15.7^{\circ} \mathrm{C}$ and $60.00 \% \mathrm{RH}$. The population of the predators was fluctuated showed that three peaks. The first one took place in the $2^{\text {nd }}$ week of February with count of 35 predators/ 524 aphids , synchronized with the peak of the aphid, at means of $14.9^{\circ} \mathrm{C}$ and $57.2 \% \mathrm{RH}$. The second peak of 70 individuals / 711 aphids was recorded in the first week of March at means of $22.4{ }^{\circ} \mathrm{C}$ and $49.57 \% \mathrm{RH}$. The third and highest one, 81 individuals / 194 aphids, took place in the $2^{\text {nd }}$ week of April at mean of $26.4^{\circ} \mathrm{C}$ and $40.7 \%$ RH. The maximum monthly total count, 273 predators / 2132 aphids was recorded during March, while the minimum one, 18 predators / 401 aphids, was obtained during January. The predators: prey ratio during the season showed a mean of 1: 7.29.

As shown in the second season (Table 5), the aphidophagous predators started to appear in the 1st week of January 2017 with count of two individuals, while the initial aphids infestation was recorded in the last week of December 2016, one week later. The number of the predators increased gradually, reaching its first peak in the 2nd week of February with value of 47 predators/ 472 aphids at means of $15.3^{\circ} \mathrm{C}$ and $63.2 \% \mathrm{RH}$. The second peak of 90 predators / 1021 aphids, was recorded in the 1st week of March, synchronized with the peak of the aphids at means of $21.3^{\circ} \mathrm{C}$ and $58.2 \% \mathrm{RH}$. While the third peak 40 individuals / 1027 aphids, took place in the 1st week of April at means of $20.3^{\circ} \mathrm{C}$ and $59.2 \% \mathrm{RH}$. The maximum 

recorded during March, while the minimum one, 48 predators /1602 aphids was obtained during January. The ratio of the predators : prey during this season was obviously higher as compared with the first season $(1: 23.25)$.

Statistical analysis in (Table 6) indicated that there were positive significant and positive highly significant correlations between aphids and predators count during the two successive seasons, whereas (r) values were $0.559^{*}$ and $0.607 * *$ during the first and second seasons, respectively.

Table 6. Simple correlation and simple regression between weekly numbers of aphids and numbers of predators on wheat plants in newly reclaimed sandy area at ElKhattara district, Sharkia Governorate during the two successive growing seasons, 2015-2016 and 2016-2017.

\begin{tabular}{lcc}
\hline Season & r (Values) & b ( Values) \\
\hline First season (2015-2016) & $0.559^{*}$ & 62.908 \\
Second season (2016-2017) & $0.607 * *$ & 69.971 \\
\hline$*=$ Significant & $* *=$ Highly significant
\end{tabular}

Obtained results are in accordance with the findings of El-Heneidy et al. (2004) who stated that the population density of the predators depended on the densities of aphids and reached its maximum value during February and March, monthly total count, 243 predators/ 3566 aphids was

then decreased at the end of the season. Abd EL-Megid et al. (2007) reported that the highest count of the predators was detected during the third and fourth week of March with maximum value of 10 and 13 predators, synchronized with 69 and 37 aphids respectively. The maximum monthly total number, 55 predators, was recorded during March . The mean ratio of predators : prey during this season was 1 : 12.04 .

3. Survey and relative densities of the parasitoids and the parasitism percentages :

1. Survey and relative densities of the parasitoids :

Data obtained in Table (7) indicated that five hymenopterous primary parasitoids species were recorded from collected aphids during 2015-2016 and 2016-2017 growing seasons. The primary parasitoids could be arranged descendingly according to their general relative densities during the two seasons of study as follows: Diaeretiella rapae (M'Intosh), Aphidius colemani Viereck, Aphidius matricariae Haliday, Ephedrus sp. and Praon sp. (Aphidiidae) with 35.32, 27.12, 23.15, 10.05 and 4.36 of the total collected parasitoids, successively.

Diaeretiella rapae was the predominant parasitoid reared from the host aphids. It composed $35.90 \%$ and 34.91 $\%$ of all recorded parasitoids in the first and second seasons, respectively.

Table 7. Survey and relative densities of aphid parasitoids on wheat plants cultivated in newly reclaimed sandy area at El- Khattara district, Sharkia Governorate during 2015 - 2016 and 2016 - 2017 growing seasons.

\begin{tabular}{lcccccc}
\hline \multirow{2}{*}{ Species } & \multicolumn{2}{c}{$\mathbf{2 0 1 5 - 2 0 1 6}$} & \multicolumn{2}{c}{$\mathbf{2 0 1 6 - 2 0 1 7}$} & \multicolumn{2}{c}{ General } \\
\cline { 2 - 7 } & Number & $\mathbf{\%}$ & Number & \% & Number & \% \\
\hline Diaeretiella rapae (M'Intosh) & 122 & 35.90 & 155 & 34.91 & 267 & 35.32 \\
Aphidius colemani Viereck & 90 & 28.85 & 115 & 25.90 & 205 & 27.12 \\
Aphidius matricariae Haliday & 75 & 24.04 & 100 & 22.52 & 175 & 23.15 \\
Ephedrus sp. & 25 & 8.01 & 51 & 11.49 & 76 & 10.05 \\
Praon sp. & 10 & 3.20 & 23 & 5.18 & 33 & 4.36 \\
Total & 312 & 100.00 & 444 & 100.00 & 756 & 100.00 \\
\hline
\end{tabular}

Different results are recorded by several investigators as follows : El-Heneidy et al., (1991) indicated that parasitoids, Diaeretiella rapae, Aphidius spp., Trioxys spp. and Proon spp. attack cereal aphids infested wheat plants. Ahmed et al. (2016) reported that Diuraphis moxia attack cereal aphids on wheat plants. Junhe et al. (2017) in China, recorded 12 hymenopterous primary parasitoid species parasitized on cereal aphids infesting wheat plants namely, Aphidius avenae, A. gifuensis, A. sichuanensi, Lysiphlebus confuses, Praon Vulucre, P. oriertale, P. rhopalosiphum, Triaxys asiaticus, Trioxys sp. and Taxares sp. A. avenae and A. gifuensis .

\section{Parasitism percentages:}

In the first season the results in (Table 8), cleared that the parasitism occurred during the period from the 4th week of January till the 3rd week of April. The parasitism percentages fluctuated to recorded three peaks. The first one , 7.16\% was found in the 3rd week of February at means of $20.3{ }^{\circ} \mathrm{C}$ and $46.4 \% \mathrm{RH}$. The second peak , $15.32 \%$, took place in the end of March at means of $21.6{ }^{\circ} \mathrm{C}$ and $43.8 \%$ $\mathrm{RH}$. The third and highest one, $15.87 \%$, occurred in the $3 \mathrm{rd}$ week of April at means of $25.8{ }^{\circ} \mathrm{C}$ and $44.7 \% \mathrm{RH}$. The highest monthly mean of parasitism percentages, $8.96 \%$ was obtained during April, while the lowest one with value of $1.25 \%$, was recorded during January. Generally, the mean percentages of parasitism throughout the season, $6.41 \%$ was obviously higher as compared with that in the second season.

The obtained results in Table (8), revealed that the parasitism in the second season was recorded during the period from the 5th week of January till the 2nd week of May. The parasitism percentages were fluctuated to recorded two peaks. The first one, $5.92 \%$, was found in the 2 nd week of March at means of $19.9{ }^{\circ} \mathrm{C}$ and $63.3 \% \mathrm{RH}$. The second peak , $6.12 \%$, took place in the 4th week of April at means of $22.3^{\circ} \mathrm{C}$ and $53.9 \% \mathrm{RH}$. The highest monthly mean of parasitism percentages $4.92 \%$, was detected during May, while the lowest value, $0.50 \%$, was found during January. Generally, the mean percentage of parasitism during the whole season was $3.60 \%$.

Statistical analysis (Table 9) indicated that there were positive highly significant correlations between weekly numbers of the aphid and numbers of emerged parasitoids, being $\left(\mathrm{r}=0.830^{* *}\right)$ and $\left(\mathrm{r}=0.877^{* *}\right)$ during the first and second seasons, successively.

Ahmad et al. (2016) who mentioned that the parasitism of cereal aphids infesting wheat plants by a braconid species occurred in $3^{\text {rd }}$ week of February and reached a peak in March $(0.25 \%)$. 
Youssif, M. A. I. et al.

Table 8. Parasitism percentages of aphids infesting wheat plants cultivated in newly reclaimed sandy area at El- Khattara district, Sharkia Governorate during 2015-2016 and 2016-2017 growing seasons.

\begin{tabular}{|c|c|c|c|c|c|c|c|c|c|c|}
\hline \multirow{4}{*}{$\begin{array}{l}\text { Weekly date of } \\
\text { samples }\end{array}$} & \multicolumn{4}{|c|}{ Number of } & \multirow{2}{*}{\multicolumn{2}{|c|}{ Parasitism \% }} & \multicolumn{4}{|c|}{ Corresponding means of } \\
\hline & \multicolumn{2}{|c|}{ collected aphids } & \multicolumn{2}{|c|}{ emerged parasitoids } & & & \multicolumn{2}{|c|}{ Temp. ${ }^{\circ} \mathrm{C}$} & \multicolumn{2}{|c|}{ R H\% } \\
\hline & 2015- & 2016- & 2015- & 2016- & 2015- & 2016- & $2015-$ & $2016-$ & 2015 & $2016-$ \\
\hline & 2016 & 2017 & 2016 & 2017 & 2016 & 2017 & 2016 & 2017 & 2016 & 2017 \\
\hline Dec. $.4^{\text {th }}$ & 0 & 20 & 0 & 0 & 0.00 & 0.00 & 15.7 & 18.0 & 63.43 & 59.5 \\
\hline Total & 0 & 20 & 0 & 0 & & & & & & \\
\hline Mean & & & & & 0.00 & 0.00 & & & & \\
\hline Jan., $1^{s t} 2016$ & 25 & 60 & 0 & 0 & 0.00 & 0.00 & 14.4 & 18.3 & 50.00 & 61.5 \\
\hline $2^{n d}$ & 66 & 133 & 0 & 0 & 0.00 & 0.00 & 15.7 & 17.2 & 60.00 & 60.2 \\
\hline $3^{r d}$ & 90 & 242 & 0 & 0 & 0.00 & 0.00 & 14.3 & 17.7 & 53.43 & 60.0 \\
\hline $4^{\text {th }}$ & 220 & 461 & 5 & 0 & 2.27 & 0.00 & 11.7 & 16.7 & 66.71 & 63.2 \\
\hline $5^{\text {th }}$ & - & 706 & - & 8 & - & 1.13 & - & 16.3 & - & 60.1 \\
\hline Total & 401 & 1602 & 5 & 8 & & & & & & \\
\hline Mean & & & & & 1.25 & 0.50 & & & & \\
\hline Feb., $1^{s t}$ & 352 & 878 & 12 & 16 & 3.41 & 1.82 & 13.0 & 18.5 & 67.59 & 59.3 \\
\hline $2^{\text {nd }}$ & 524 & 472 & 25 & 12 & 4.77 & 2.54 & 14.9 & 15.3 & 57.29 & 63.2 \\
\hline $3^{r d}$ & 419 & 633 & 30 & 20 & 7.16 & 3.16 & 20.3 & 16.3 & 46.43 & 63.7 \\
\hline $4^{\text {th }}$ & 504 & 782 & 32 & 30 & 6.35 & 3.84 & 19.5 & 18.5 & 51.00 & 59.3 \\
\hline Total & 1799 & 2765 & 99 & 78 & & & & & & \\
\hline Mean & & & & & 5.50 & 2.82 & & & & \\
\hline Mar., $1^{s t}$ & 711 & 1021 & 35 & 40 & 4.92 & 3.92 & 22.4 & 21.3 & 49.57 & 58.2 \\
\hline $2^{n d}$ & 509 & 845 & 30 & 50 & 5.89 & 5.92 & 20.5 & 19.9 & 48.71 & 63.3 \\
\hline $3^{r d}$ & 389 & 782 & 25 & 36 & 6.43 & 4.60 & 21.8 & 19.2 & 43.00 & 62.1 \\
\hline $4^{t h}$ & 275 & 918 & 32 & 40 & 11.64 & 4.36 & 20.0 & 18.3 & 47.71 & 60.3 \\
\hline $5^{t h}$ & 248 & - & 38 & - & 15.32 & - & 21.6 & - & 43.86 & - \\
\hline Total & 2132 & 3566 & 160 & 166 & & & & & & \\
\hline Mean & & & & & 7.50 & 4.66 & & & & \\
\hline Apri., $1^{s t}$ & 274 & 1027 & 20 & 44 & 7.30 & 4.28 & 22.7 & 20.3 & 53.71 & 59.2 \\
\hline $2^{\text {nd }}$ & 194 & 1503 & 18 & 52 & 9.28 & 3.46 & 26.4 & 20.0 & 40.71 & 53.9 \\
\hline $3^{r a}$ & 63 & 1050 & 10 & 50 & 15.87 & 4.76 & 25.8 & 25.9 & 44.71 & 50.3 \\
\hline $4^{\text {th }}$ & 5 & 490 & 0 & 30 & 0.00 & 6.12 & 28.2 & 22.3 & 36.43 & 53.9 \\
\hline Total & 536 & 4070 & 48 & 176 & & & & & & \\
\hline Mean & & & & & 8.96 & 4.32 & & & & \\
\hline May, $1^{s t}$ & - & 285 & - & 16 & - & 5.61 & - & 23.5 & - & 55.2 \\
\hline $2^{n d}$ & - & 40 & - & 0 & - & 0.00 & - & 24.9 & - & 50.3 \\
\hline Total & - & 325 & - & 16 & - & & & & & \\
\hline Mean & & & & & & 4.92 & & & & \\
\hline $\begin{array}{l}\text { General total } \\
\text { General mean }\end{array}$ & 4868 & 12348 & 312 & 444 & 6.41 & 3.60 & & & & \\
\hline
\end{tabular}

Table 9. Simple correlation and simple regression between weekly numbers of aphids and the numbers of emerged parasitoids on wheat plants in newly reclaimed sandy area at ElKhattara district, Sharkia Governorate during the two successive growing seasons, 2015-2016 and 2016-2017.

\begin{tabular}{lcc}
\hline Seasons & r (Values) & b ( Values) \\
\hline First season $(2015-2016)$ & $0.830^{* *}$ & 50.82 \\
Second season $(2016-2017)$ & $0.877^{* *}$ & 76.840 \\
\hline
\end{tabular}

$* *=$ Highly significant

\section{REFERENCES}

Ahmad,U.S.R;M.Nadeem;K.Tarig; A. Ali; G. Naz; H. Badshan; A. Khan and S. Rahmen (2016). Seasonal abundance of aphids and their associated natural enemies with respect of planting dates in water crop of Pakistan. J. Agric. Environ. Sci., 16 (6): 1071-1078.

Abd El-Megid Jasmin E.; M. A. El-Maghraby; K. A. A. Hammad and I. M. El-Baz (2007). Cereal aphids on wheat and their associated aphidophagous insect predators. Zagazig J. Agric. Res., 34 (3): 559-577.
Al-Aish-Hana; I. M. El-Ghariani and A. H. Al-Mabruk (2004). Survey of cereal aphids and their natural enemies and effect of the predator Coccinella septempunctata L., on cereal aphids in Al-Jabal Al-Kadar region, Libya . Egypt J. Biol. Cont., 14 (1): $285-290$.

Alhag, E. A.A.; A. Al-Rokaibah and A.A. Zaitoon (1996). Natural enemies of cereal aphids in sprinkler - irrigated wheat in central Saudi Arabia. Bull. Fac. Agric. Cairo Univ., 47 (4): 649-663.

Ali, M.A. and Y. A. Darwish (1990). Incidence of the greenbug, Schizaphis graminum (Rondani) (Homo: Aphidiade) on wheat in Upper Egypt. Assiut J. Agric. Sci., 21 (2): 183-190.

Ali, M.A.; Y. A. Darwish and M.A.A. Abdel-Rahman (1991). Abundance and distribution of cereal aphids on various parts of wheat in Upper Egypt . Ibid 22 (1): 191-200.

Anonymous, (2017). Economic Affairs Sector, Ministry o Agriculture and Land Reclamation, ARE. Winter Crops. Agricultural Statistics Volume 1, May, 2017. 
Atwal, A. S. (1976). Agricultural pests of India and Southeast Asia. Kalyani Publisher Delhi. Pp. 502.

COSTAT (Computer Program) 2005. Version 6.311, Copyright (C), Coltart Software 798 Lighthouse Ave. PMB 320, Monterey, CA, 93940, USA.

El-Bouhssini, M.; F. Bakkoush; M. Assol and I. Ghariani (2003). Survey of major insect pests of wheat and barley in Libya . Aab. J. of Plant Prot., 21 (1): 35-38.

El-Heneidy, A.H. and A.A. Attia (1988). Evaluation of the role of parasitoids and predators associated with aphids in wheat fields Egypt. Bull. Ento. Soc., 17: 137-147.

El-Heneidy, A.H. (1991). Seasonal abundance of aphids and their natural enemies in upper Egypt. Egypt. J. Biol. Pest, Cont., 1(1): 5-10.

El-Heneidy, A.H.; G. N. Rezk ; M. A. Abdel-Megeed and Salwa, S. M. Abdel-Samad (2004). Comparative study of cereal aphids species and their associated predators and parasitoids in two different wheat regions in Egypt . Egypt J. Biol. Pest Cont., 14 (1): 217-224 (Proceeding of $1^{\text {st }}$ Arab Conference for Applied Biological Pest Control, Cairo, Egypt, 5-7 April 2004).

El-Serafy, H. A. (1999). Population density of cereal aphids parasitoids and their role in suppressing cereal aphids on wheat plantations at Mansoura district. Archives of Phytopath. and Plant Prot. , 32 (3) : 257-264.

Ghanem, A.A. and M.A. El-Adl (1983). Aphids infesting wheat and the effect of their predators in suppressing its population in the field at Mansoura district, Egypt. J. Agric. Sci. Mansoura Univ., 8 (4): 958-968.

Hatchett, A. H. ; K. J. Stacks and J. A. Webster (1987). Insect and mite pests of wheat in E. G. Heyene (ed), wheat and wheat improvement . Madison Wisconsin, USA. pp: 625-668.

Junhe, L.; Y. Yan; A. Aphid; W. Ningtao; Z. Zihua and Y. Mingfu (2017). Effect of wheat-maize intercropping on population dynamics of wheat aphids and their natural enemies. J. of sustainability, China, $9: 1-15$.
Khan , S. A. ; N. Hussain; F. Ulah and Y. Haya (2003). Screening of wheat genotypes for resistance against cereal aphids. Sarhad J. of Agric., 23 (2): 426-434.

Picard, K. (1987). Sumicicin 10, a modern compound for aphid control in wheat. Gesunde Pflamzen, 39 (6): 268-272.

Rana, J. S. (2005). Role of Coccinella septempunctata (L.) in management of cereal aphid, Sitobion avenae (F.) in subtropical wheat crop ecosystem Depart. Entom. CCS., Haryana. Agric. Univ. Hisar, 125. India.

Sajioqi, A.U.R. ; K. Kanran and R. S. Sadur (2009). Integrated management of potato-peach aphid, Myzus persicae (Sulzer). Sarhad J. Agric., 25 (4) : 573-580.

Sehüler, T. H.; G. M. Poppy; R. P. J. Potting; I. Denhoim and B.R. Kerry (1999). Interactions between insect tolerant genetically modified plants and natural enemies. Gene flow and agriculture: relevance for transgenic crops. Proceedings of a symposium held at Keele, UK on Proceedings No. 72.

Shah, P. (1994). Cereal crop. In E. Bashir and R. Bantel (ed.) Crop production National Book Foundation Islamabad Pakistan. Pp. 223-249.

Tantawi, A. M. (1985). Studies on wheat aphids in Egypt II. Germplasm evaluation and crop loss assessment . Rachis , 4 (2): 26-27.

Tawfik, M. F. S. and M.M. El-Husseini (2002). Review Article: Natural enemies of commonly distributed insect pests in Egyptian Agroecosystems. Egypt. J. Biol. Pest Control, 12 (2): 131-144.

Vandereycken, A.; D. Durieux; E. Joie; F. Francis; H. Francis and J. Verheggen (2015). Aphid species and associated natural enemies in field crop : wheat about the invasive ladybird Harmonia axyridis (Coleoptera : Coccinellidae) Faunistic Entomology, 68: 3-15.

Youssef, A. A. A. (2006). Studies on some homopterous insect vectors of plant diseases. Ph. D. Thesis, Fac. Agric., Zagazig Univ.

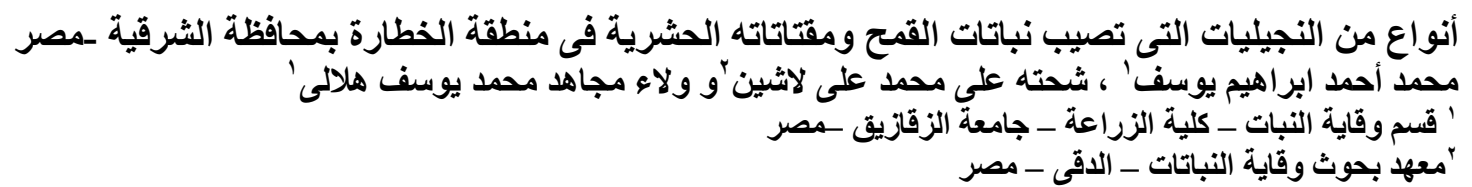

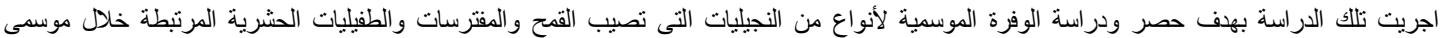

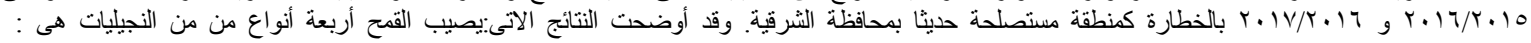
Ropalosiphum padi (Linnaeus), Schizaphis graminum (Rondani), Ropalosiphum maidis (Fitch), Macrosiphum (=Sitobion) avenae

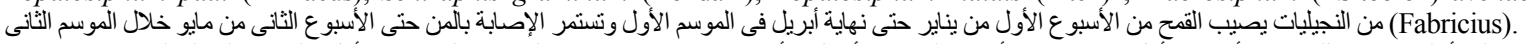

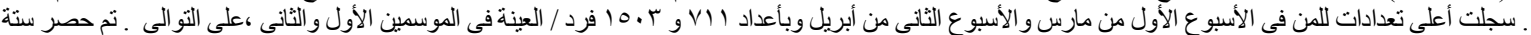

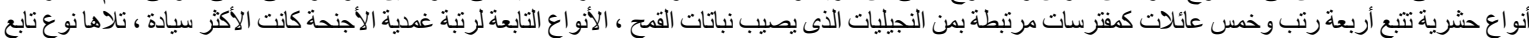

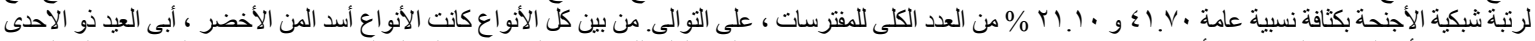

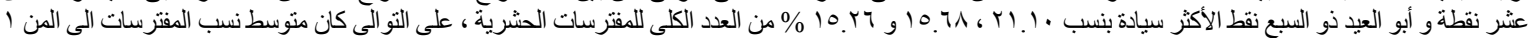

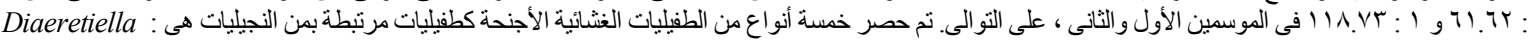

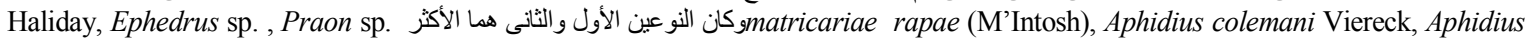

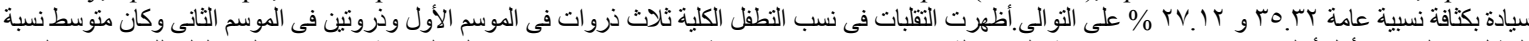

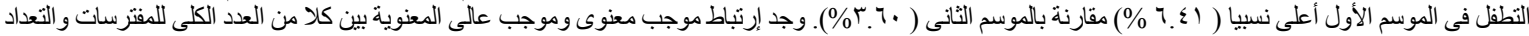

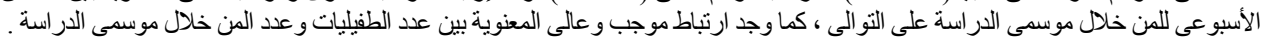

